\title{
Magnio trąšų ịtaka vasariniams miežiams skirtinguose dirvožemiuose
}

\section{Gediminas Staugaitis,}

\section{Rasa Rutkauskienè}

Lietuvos agrarinių ir miškų mokslu centro filialas,

Agrocheminiu tyrimy laboratorija, Savanoriu pr. 287, LT-50127 Kaunas

El.paštas:agrolab@agrolab.lt
2008-2010 m.Lietuvos agrarinių ir miškų mokslų centro (LAMMC)Agrocheminių tyrimų laboratorijos vegetacinių bandymų aikštelëje buvo atlikti devyni vegetaciniai bandymai iš įvairių Lietuvos vietų surinktuose skirtingo karbonatingumo dirvožemiuose. Juose buvo auginti 'Simba' veislès vasariniai miežiai, kurie buvo tręšti 2 ir $4 \mathrm{~g} \mathrm{~m}^{2}$ magnio $\left(\mathrm{Mg}\right.$ ) trąšų normomis (sutr. $\mathrm{Mg}_{20}$, nes buvo panaudota $20 \mathrm{~kg} \mathrm{ha}^{-1}$ magnio trą̌uc ir $\mathrm{Mg}_{40}-40 \mathrm{~kg} \mathrm{ha}^{-1}$ ). Tyrimai parodè, kad $\mathrm{Mg}_{20}$ norma iš esmès didino vasarinių miežių grūdų derlių tik mažo karbonatingumo dirvožemiuose. Tokiuose dirvožemiuose judraus magnio $\left(\mathrm{Mg}_{\mathrm{A}-\mathrm{L}}\right)$ kiekis sudaré $135-273 \mathrm{mg} \mathrm{kg}^{-1}$, kalcio $\left(\mathrm{Ca}_{\mathrm{A}-\mathrm{L}}\right)$ - 912-1 $894 \mathrm{mg} \mathrm{kg}^{-1}$, karbonatai - 0-0,08\%, $\mathrm{pH}_{\mathrm{KCl}}-4,3-5,3$, o vasarinių miežių grūdų derliaus priedas tręšiant $\mathrm{Mg}_{20}$ norma buvo 4,4 \%. Šiaudų derlių magnio trą̧šos $\mathrm{Mg}_{20}$ ir $\mathrm{Mg}_{40}$ vidutiniškai didino 4,1 \%, tačiau esminiai skirtumai gauti tik 4 bandymuose. Magnio trąšos, nepriklausomai nuo dirvožemio karbonatingumo, daugelyje bandymų iš esmès didino žaliųju proteinų kiekị grūduose ir šiauduose. $\mathrm{Mg}_{20}$ norma grūduose žaliuosius proteinus esminiu skirtumu padidino 8,2 \% ir $\mathrm{Mg}_{40}-13,6 \%$, o šiauduose $\mathrm{Mg}_{20}-9,9 \%$ ir esminiu skirtumu $\mathrm{Mg}_{40}-15,1 \%$. Magnio trąšos neturejjo ittakos magnio kiekiui grūduose, tačiau jo daugiau nustatyta karbonatinguose dirvožemiuose išaugintuose grūduose. Magnio kiekis nuo magnio trąšų šiauduose nesikeité, tačiau karštais metais jo kiekis didèjo. Magnio augalai bandymuose vidutiniškai sunaudojo $0,71 \mathrm{~g} \mathrm{~m}^{2}$ arba $44 \% \mathrm{Mg}_{20}$ normos kiekio. Koreliacinè analizè parodè, kad miežiu grūdų derlius priklausè nuo judriojo magnio kiekio dirvožemyje, nustatyto A-L metodu $(r=0,616, P<0,01)$ ir vandens ištraukoje $(r=0,735, P<0,01)$. Kai judrusis magnis dirvožemyje buvo nustatytas kalcio chlorido, kalio chlorido, amonio acetato ir Mehlich 3 metodais, koreliacinès priklausomybès negauta.

Raktažodžiai: vasariniai miežiai, magnio trąšos, magnis dirvožemyje

\section{IVADAS}

Magnis - svarbus makroelementas augalų mityboje, atliekantis pagrindines fiziologines funkcijas. Jis dalyvauja fotosintezeje, nes ieina $\mathfrak{i}$ chlorofilo sudetti, dalyvauja pernešant augale fosforą, cukrų ir krakmolo sintezėje, daugelio fermentų veikloje bei kituose fiziologiniuose ir biocheminiuose procesuose (Bergman, 1988; Carmak, Kirkby, 2007; Roemheld, Kirkby, 2007).

Požiūris ị magnio poreikị žemès ūkio augalams, o tuo pačiu tręšimą magnio trąšomis, ịvairiose šalyse skirtingas. Tai parodè 2006-2007 m. vokie- čių organizacijos VDLUFA organizuoti dešimties šalių tarplaboratoriniai tyrimai (Fotyma, Dobers, 2008). Ivairiose Vidurio ir Rytų Europos šalyse magnio (Mg) trąšų norma, paskaičiuota vienai tonai derliaus kartu įvertinant šalutinę produkciją, žieminiams kviečiams svyravo $1,2-3,2 \mathrm{~kg} \mathrm{t}^{-1}$ intervalo ribose, žieminiams rapsams - 4,5-6,0, bulvèms - 0-0,91 kg t ${ }^{-1}$ ribose (Fotyma, Dobers, 2008). Vokietijoje vasariniams miežiams rekomenduojama magnio $(\mathrm{MgO})$ trąšų norma, kai planuojamas grūdų derlius $4 \mathrm{t} \mathrm{ha}^{-1}$, yra $20-25 \mathrm{~kg} \mathrm{ha}^{-1}$, kai $5 \mathrm{t} \mathrm{ha}^{-1}-25-30$, kai $6 \mathrm{t} \mathrm{ha}^{-1}-30-35 \mathrm{~kg} \mathrm{ha}^{-1}$. Tai yra tik vidutinès normos ir jos dar koreguojamos 
pagal dirvožemio tyrimus įvertinant dirvožemio granuliometrinę sudètị, judriojo magnio kiekị. Čia iš viso yra išskiriamos 5 judriojo magnio turtingumo grupès (Schweder, Kape, 2004). Lenkijoje išskiriamos 5 judriojo magnio turtingumo grupès ir 5 granuliometrinès sudèties klasès, o vidutinè magnio $(\mathrm{Mg})$ trąšu norma vienai tonai miežių grūdų išauginti yra $2,3 \mathrm{~kg} \mathrm{t}^{-1}$ (Jadczyszyn, 2009). Žemès ūkio augalai, miežiai irgi, tręšiami daugelyje Šiaurès, Vidurio ir Rytų Europos šalių, kaip Švedijoje, Suomijoje, Austrijoje, Vokietijoje, Čekijoje, Slovakijoje, Vengrijoje, Lenkijoje, o magnio trąšu normų nustatymai remiasi magnio poreikiu derliui išauginti, judriojo magnio kiekiu dirvožemyje ir dirvožemio granuliometrine sudètimi (Schweder, Kape, 2004; Fotyma, Dobers, 2008; Riktlinjer..., 2008; Budnakova, Čermak, 2009; Jadczyszyn, 2009). Kad magnio trąšos teigiamai veikia žemès ūkio augalus, teigia L. Ristimäki bei A. E. Johnston, apibendrinę nemažai vykdytų bandymų bei tręšimo rekomendacijų (Johnston, 2007; Ristimäki, 2007). Optimalus augalo apsirūpinimas magniu palengvina abiotinių aplinkos veiksnių ittaką, pvz., sausros, karščio, šviesos intensyvumo (Carmak, Kirkby, 2007). Mažai magnio yra smèlio dirvožemiuose, todèl čia tręšimas magnio trąšomis duoda didžiausią efektą (Mayland, Wilkinson, 1989).

Baltijos šalyse tręšimui magniu skiriamas mažesnis dèmesys (Fotyma, Dobers, 2008). Lietuvoje parengtų žemès ūkio augalų tręšimo magniu rekomendacijų nèra. Iki 1992 m. šalyje vyko rūgščių dirvų intensyvus kalkinimas, tuo pačiu laukai buvo patręšiami magniu. Vyrauja nuomonè, kad nerūgščiose dirvose augalams prieinamo magnio užtenka, o rūgščios - kalkinimo metu magniu pasitręšia kartu su klintmilčiais, kuriuose yra apie $10 \%$ magnio oksido. Tai tiesa, nes tyrimai rodo, kad kai dirvožemyje $\mathrm{pH}_{\mathrm{KCl}}<6,0$ judriojo magnio vidutinis kiekis, nustatytas A-L meto$\mathrm{du}$, buvo $173 \mathrm{mg} \mathrm{kg}^{-1}$, kai 6,1-7,0 - $573 \mathrm{mg} \mathrm{kg}^{-1}$, $>7,0$ - $2639 \mathrm{mg} \mathrm{kg}^{-1}$ (Staugaitis, Rutkauskienè, 2010). Nurodoma, kad kalkinimas dirvožemyje padidina sorbuotų bazių sumą, tuo pačiu ir augalų ìsavinamo magnio kieki (Mažvila ir kt., 2006; Tripolskaja ir kt., 2010). Deja, intensyvūs kalkinimo darbai šalyje jau seniai nevykdomi, o kaip augalus veikia mineralinès magnio trąšos mokslinejje literatūroje aprašytų vietinių tyrimų neradome. Todèl mūsų tyrimų tikslas buvo nustatyti, kaip mineralinès magnio trąšos ịvairiuose Lietuvos dirvožemiuose veikè miežių derlių ir kokybę. Siekème bandymus atlikti kuo ịvairesniuose dirvožemiuose.

\section{METODAI IR SĄLYGOS}

Vasarinių miežių tręšimo magniu tyrimai buvo atlikti 2008-2010 m. Kaune, LAMMC Agrocheminių tyrimų laboratorijos vegetacinių bandymu plote. Vegetaciniuose induose auginti vasariniai miežiai prieš sèją magniu tręšti pagal schemą: 1) magniu netręšti (sutr. $\mathrm{Mg}_{0}$ ); 2) tręšti $0,075 \mathrm{~g}$ magnio (Mg) vienam indui, kas sudarytų $2 \mathrm{~g} \mathrm{~m}^{2}$ arba $20 \mathrm{~kg} \mathrm{ha}^{-1}$ magnio normą $\left.\left(\mathrm{Mg}_{20}\right) ; 3\right)$ tręšti $0,15 \mathrm{~g}$ magnio $(\mathrm{Mg})$ vienam indui, tai būtų $4 \mathrm{~g} \mathrm{~m}^{2}$ arba $40 \mathrm{~kg} \mathrm{ha}^{-1}$ magnio norma $\left(\mathrm{Mg}_{40}\right)$.

Tręšimo bandymuose naudotų cilindro formos plastmasinių indų skersmuo buvo $22 \mathrm{~cm}$, aukštis $-17 \mathrm{~cm}$, i juos buvo îpilta po 61 žemès. Tręšimui naudotas magnio sulfatas, kuri ištirpinę vandenyje įterpème ị vegetacinius indus. Prieš sèją visiems indams buvo atliktas foninis vasarinių miežių tręšimas $\mathrm{N}_{80} \mathrm{P}_{40} \mathrm{~K}_{107}$ norma, t. y. vienam indui buvo itterpiama $0,3 \mathrm{~g} \mathrm{~N}, 0,15 \mathrm{~g} \mathrm{P}_{2} \mathrm{O}_{5}$, $0,4 \mathrm{~g} \mathrm{~K}_{2} \mathrm{O}$ trąšų. Naudotas ištirpintas vandenyje karbamidas, paprastasis superfosfatas, kalio chloridas. Kiekvienas tręšimo variantas turèjo $4 \mathrm{pa}$ kartojimus.

Vasarinių miežių veislès 'Simba' induose sèjome po 12 sèklų, po sudygimo augti buvo palikta po 10 daigų. Kiekvienais metais bandymuose vasariniai miežiai buvo sèti gegužès mèn. 8-10 d. Derlius nuimtas 2008 ir $2010 \mathrm{~m}$. rugpjūčio 4 d., o 2009 m. - rugpjūčio 6 d. Augalų vegetacijos metu buvo laistoma distiliuotu vandeniu rankiniu būdu. Naudotos šios apsaugos priemonès: insekticidas Actara $\left(3 \mathrm{mg} \mathrm{l}^{-1}\right)$ ir fungicidas Allegro Plus (60 $\left.\mathrm{mg} \mathrm{l}^{-1}\right)$, purkšta vienu metu ir vieną kartą bamblèjimo pradžioje - pasirodžius pirmiesiems akuotams, pastebejus pirmuosius amarus bei dryžligès požymius, tačiau $2010 \mathrm{~m}$. nepaisant panaudoto fungicido dryžligè vis dèlto išplito. Miežių grūdų derlių nustatème esant $15 \%$ drègnumui, šiaudų - sausoje medžiagoje. Grūduose bendrą azotą ịvertinome Kjeldalio metodu, o žaliuosius proteinus skaičiavome bendro azoto kieki padauginę iš koeficiento 6,25. Magnio kieki grūduose ir šiauduose nustateme sausojo deginimo metodu analizuojant atominès 
absorbcijos spektrometru Aanalyst 200 (Aanalyst 200AA Spectrometer, PerkinElmer (JAV)).

Kiekvienais metais vykdėme tris vasarinių miežių tręšimo magniu bandymus, kurių kiekvienas turèjo skirtingą dirvožemị. Iš viso per tris metus atlikome 9 vasarinių miežių tręšimo magniu bandymus. Kiekvienam bandymui specialiai atrinktuose plotuose dirvožemi èmème iš ariamojo sluoksnio po augusių vasarinių javų. Dirvožemius pagal kokybès reikalavimus skirsteme i 3 sąlygines grupes:

1) mažai karbonatingi, turintys judriojo magnio (A-L) $<200 \mathrm{mg} \mathrm{kg}^{-1}$, judriojo kalcio (A-L) apie $1000 \mathrm{mg} \mathrm{kg}^{-1}, \mathrm{pH}_{\mathrm{KCl}}<5,0$, karbonatu $<0,1 \%$;

2) vidutiniškai karbonatingi, turintys judriojo magnio (A-L) 250-300 $\mathrm{mg} \mathrm{kg}^{-1}$, judriojo kalcio (A-L) apie $2000 \mathrm{mg} \mathrm{kg}^{-1}, \mathrm{pH}_{\mathrm{KCl}} 5,1-6,0$, karbonatu $0,1-0,3 \%$;

3) karbonatingi, turintys judriojo magnio (AL) $>500 \mathrm{mg} \mathrm{kg}{ }^{-1}$, judriojo kalcio (A-L) apie $4000 \mathrm{mg} \mathrm{kg}^{-1}, \mathrm{pH}_{\mathrm{KCl}}>6,5$, karbonatų $>0,3 \%$.

Stengèmès kiekvienais metais bandymuose turèti po vieną tokios grupès dirvožemị. Trejų metų patirtis parode, kad, net ir atlikus lauke išankstinius tyrimus, dirvožemius pagal numatytus kriterijus parinkti buvo sunku. Žemès buvo suvežtos iš 12 vietų, tačiau mūsų sąlygini grupavimą atitiko tik 9 dirvožemio èminiai, todèl juose ir atlikome vegetacinius bandymus.

Atvežtuose dirvožemio èminiuose judriojo magnio kiekis buvo nustatytas 6 metodais:

1. Egner-Riehm-Domingo metodu (sutr. A-L); eminys ekstrahuotas A-L buferiniu tirpalu (1 M pieno rūgštis, $3 \mathrm{M}$ acto rūgštis ir $1 \mathrm{M}$ amonio acetatas, $\mathrm{pH} 3,7$ ), dirvožemio ir tirpiklio santykis 1:20, plakta 4 valandas.

2. Mehlich 3 metodu (sutr. Me-3); èminys ekstrahuotas Mehlich 3 tirpalu $(0,2 \mathrm{M}$ acto rūgštis, 0,015 $\mathrm{M}$ amonio fluoridas, $0,013 \mathrm{M}$ azoto rūgštis, $0,25 \mathrm{M}$ amonio nitratas, $0,001 \mathrm{M}$ etilendiaminotetraacto rūgštis, $\mathrm{pH} 2,5$ ), dirvožemio ir tirpiklio santykis $1: 10$, plakta 5 minutes.

3. Kalcio chlorido arba Schachtschabel metodu (sutr. $\mathrm{CaCl}_{2}$ ); èminys ekstrahuotas 0,0125 M kalcio chlorido tirpalu, dirvožemio ir tirpiklio santykis 1:20, plakta 1 valandą.

4. Kalio chlorido metodu (sutr. $\mathrm{KCl}$ ); èminys ekstrahuotas $1 \mathrm{M}$ kalio chlorido tirpalu, dirvožemio ir tirpiklio santykis 1:10, plakta 1 valandą.

5. Mainų magnis arba nustatytas amonio acetato ištraukoje (sutr. $\mathrm{NH}_{4} \mathrm{OAc}$ ). Ėminys ekstrahuotas
$1 \mathrm{M}$ amonio acetato tirpalu ( $\mathrm{pH} 7,0)$, dirvožemio ir tirpiklio santykis 1:10, plakta 1 valandą.

6 . Vandenyje tirpus magnis (sutr. $\mathrm{H}_{2} \mathrm{O}$ ); nustatytas dirvožemio ėmini ekstrahuojant vandeniu, dirvožemio ir tirpiklio santykis 1:5, plakta 1 valandą.

Atvežtuose dirvožemiuose buvo nustatytas $\mathrm{pH}_{\mathrm{KCl}}-1 \mathrm{~N} \mathrm{KCl}$ potenciometriniu metodu, judrusis fosforas, kalis, kalcis - Egner-Riehm-Domingo metodu (A-L), karbonatai - kalcimetru, humusas - perskaičiuotas iš organinès anglies, kuri nustatyta sauso deginimo būdu.

Dirvožemis. Vegetaciniuose bandymuose naudotų dirvožemių charakteristika pateikta 1 ir 2 lentelèse. Parinkome būdingus Lietuvai dirvožemius: išplautžemius (Luvisols), balkšvažemius (Albeluvisols) ir rudžemius (Cambisols). Jų granuliometrinè sudètis buvo priesmèlis arba priemolis. Humuso kiekis svyravo 1,69-3,86 \% ribose, judriojo fosforo $\left(\mathrm{P}_{2} \mathrm{O}_{5}\right)-45-253 \mathrm{mg} \mathrm{kg}$, , judriojo kalio $\left(\mathrm{K}_{2} \mathrm{O}\right)$ - 90-275 $\mathrm{mg} \mathrm{kg}^{-1}$ ribose. Tuo būdu judrusis fosforas ivvairavo net 5, o judrusis kalis 4 turtingumo grupių ribose.

Kadangi kiekvienais metais stengèmès turèti dirvožemius sąlyginai mažo, vidutinio karbonatingumo ir karbonatingus, todèl $\mathrm{pH}$, karbonatai, judriojo kalcio ir magnio kiekiai ivvairavo labai plačiose ribose: $\mathrm{pH}_{\mathrm{KCl}}-4,3-7,1$, karbonatai - 0,000,58\%, kalcis $\left(\mathrm{Ca}_{\mathrm{A}-\mathrm{L}}\right)-912-8488 \mathrm{mg} \mathrm{kg}^{-1}$, magnis $\left(\mathrm{Mg}_{\mathrm{A}-\mathrm{L}}\right)-135-1360 \mathrm{mg} \mathrm{kg}{ }^{-1}$. Itvairiais metodais dirvožemyje nustatytas judriojo magnio kiekis priklausė nuo dirvožemio karbonatingumo. Didesni magnio skirtumai ivairaus karbonatingumo dirvožemiuose gauti naudojant Egner-Riehm-Domingo ir Mehlich 3 metodus. Judriojo kalcio ir magnio santykis dirvožemiuose buvo optimalus ir svyravo $6,2-8,0$ ribose. Kadangi judriojo kalio ir magnio kiekiai dirvožemiuose labai įvairavo, tai šis santykis svyravo labai dideliame intervale: $\mathrm{K}: \mathrm{Mg}$ (AL) - nuo 0,11 iki 1,25, K:Mg (A-L:KCl) - nuo 0,34 iki 2,17.

Meteorologinès sąlygos. Bandymo vykdymo laikotarpiu 2008 ir 2009 m. gegužès mèn. oro temperatūra buvo artima daugiametei. Kritulių iškrito mažiau nei ịprasta, tačiau vasariniai miežiai buvo laistomi, todèl jie gerai sudygo. 2010 m. miežių dygimo metu praèjo stiprios liūtys, dirvožemio paviršius buvo suplūktas, todèl jie prastai dygo ir lètai augo.

$2008 \mathrm{~m}$. birželis buvo kiek šiltesnis už daugiametị vidurkị, o 2009 m. I ir II dešimtadieniai - vèsūs 


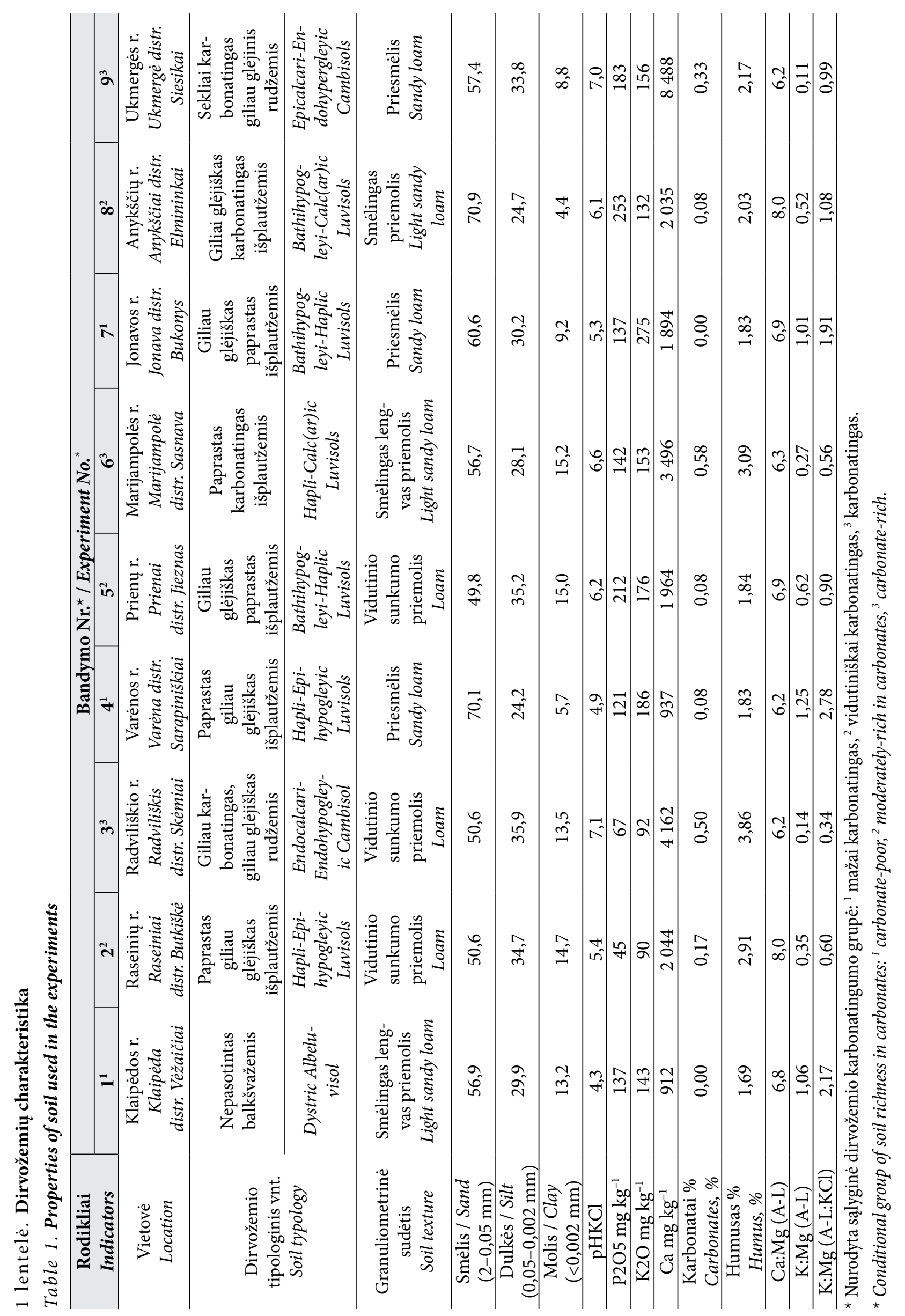


2 lentelè. Dirvožemiuose skirtingais metodais nustatytas magnio $(\mathbf{M g})$ kiekis $\left(\mathbf{m g ~} \mathbf{~ g g}^{-1}\right)$

Table 2. Magnesium (Mg) content ( $\mathrm{mg} \mathrm{kg}^{-1}$ ) in experimental soils determined using different methods

\begin{tabular}{|c|c|c|c|c|c|c|c|c|c|}
\hline \multirow{2}{*}{$\begin{array}{l}\text { Metodas } \\
\text { Method }\end{array}$} & \multicolumn{9}{|c|}{ Bandymo Nr. / Experiment No. } \\
\hline & $1^{1}$ & $2^{2}$ & $3^{3}$ & $4^{1}$ & $5^{2}$ & $6^{3}$ & $7^{1}$ & $8^{2}$ & $9^{3}$ \\
\hline A-L & 135 & 255 & 676 & 151 & 283 & 558 & 273 & 254 & 1360 \\
\hline $\mathrm{Me}-3$ & 97 & 166 & 396 & 71 & 199 & 372 & 174 & 158 & 316 \\
\hline $\mathrm{KCl}$ & 66 & 149 & 272 & 67 & 196 & 275 & 144 & 122 & 158 \\
\hline $\mathrm{NH}_{4} \mathrm{OAc}$ & 64 & 148 & 316 & 65 & 192 & 262 & 123 & 117 & 149 \\
\hline $\mathrm{CaCl}_{2}$ & 93 & 170 & 286 & 70 & 191 & 287 & 169 & 141 & 182 \\
\hline $\mathrm{H}_{2} \mathrm{O}$ & 11 & 25 & 31 & 9 & 17 & 32 & 61 & 23 & 53 \\
\hline
\end{tabular}

ir lietingi, tačiau abeji metai buvo palankūs miežių krūmijimuisi ir augimui. $2010 \mathrm{~m}$. vidutinè ménesio oro temperatūra buvo $1{ }^{\circ} \mathrm{C}$ didesnè už daugiametę, tačiau I dešimtadienyje trumpi, bet intensyvūs lietūs dar labiau suplakè dirvožemio paviršių.

2008 ir 2009 m. liepos mèn. ir rugpjūčio pirmoje dekadoje orai buvo šiltesni nei ịprasta, vidutinè dešimtadienio oro temperatūra svyravo $15,7-19,7^{\circ} \mathrm{C}$ intervale ir palankiai veikè augalų augimą bei grūdų formavimąsi varpose. $2010 \mathrm{~m}$. šiuo laikotarpiu mūsų vietos sąlygomis orai buvo labai karšti - nuo liepos pradžios net 4 dešimtadienius vidutinè paros oro temperatūra viršijo daugiametę ir buvo atitinkamai $19,8,23,8,21,9,21,4{ }^{\circ} \mathrm{C}$.

Vasarinių miežių grūdų derliui ir jų kokybei didelès ittakos turi auginimo technologija ir aplinkos veiksniai: ligų ir kenkejjų paplitimas, meteorologinès sąlygos. Analizuojant meteorologines sąlygas bandymo metu, 2008 ir $2009 \mathrm{~m}$. vertintume kaip palankius vasarinių miežių augimui, o $2010 \mathrm{~m}$. - nepalankius dèl stiprių liūčių dygimo metu ir vegetacijos pradžioje bei didelių karščiu liepos ir rugpjūčio mèn. (pav.). Dèl to $2010 \mathrm{~m}$. grūdų derlius gautas mažesnis.

\section{REZULTATAI IR JŲ APTARIMAS}

Vertinant miežių grūdų derliaus duomenis akivaizdu, kad $2010 \mathrm{~m}$. buvo mažiau palankūs vasarinių miežių augimui. Grūdų derlius gautas 35 \% mažesnis nei 2008 ir 2009 m., o grūdai tamsesni bei smulkesni. Tų metų derlių sumažino jų dygimo metu

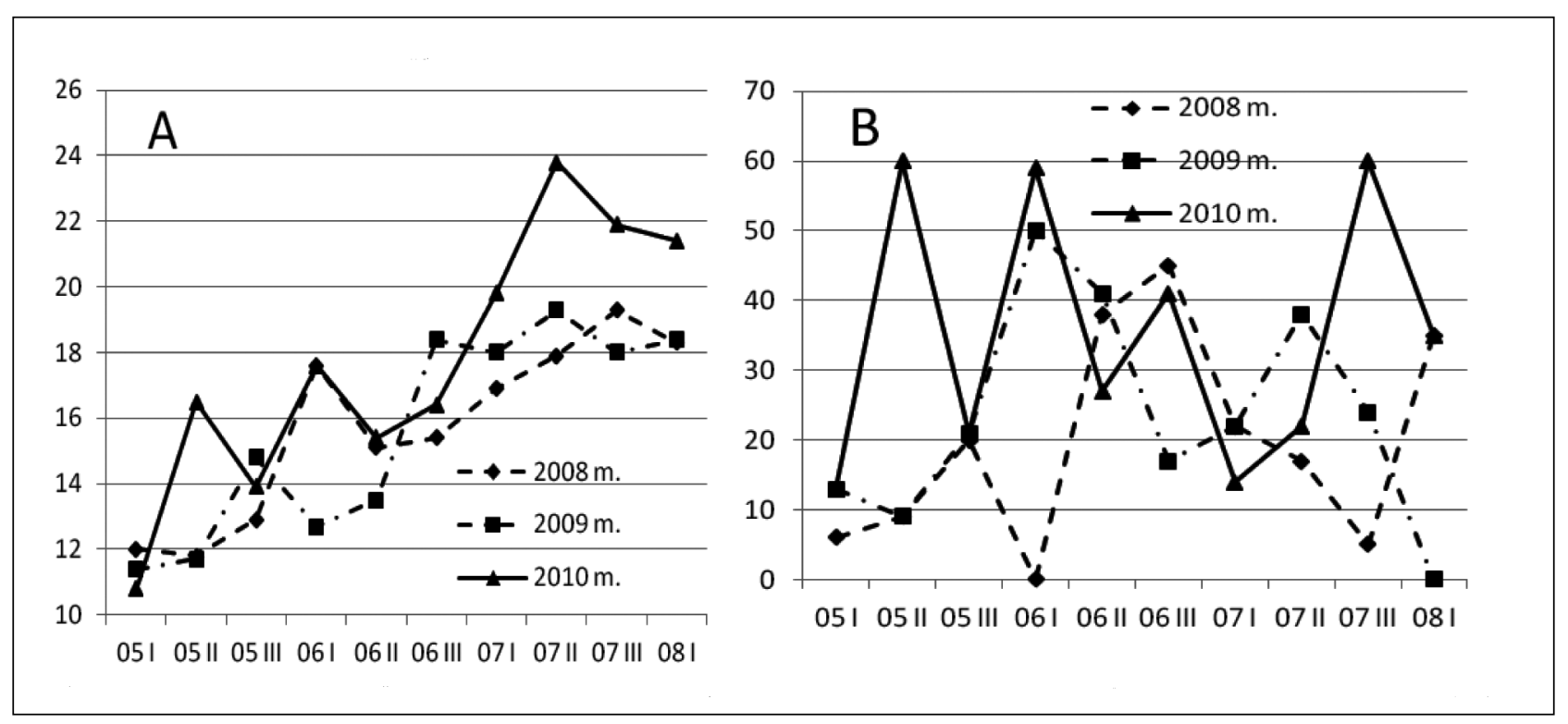

Pav. Bandymų laikotarpio atskirų metų dekadų vidutinès paros oro temperatūros ${ }^{\circ} \mathrm{C}(\mathrm{A})$ ir iškritęs kritulių kiekis mm (B)

Figure. Ten-day means of the 24-hour air temperature $\left({ }^{\circ} \mathrm{C}\right)(\mathrm{A})$ and the precipitation level $(\mathrm{mm})$

(B) in 2008-2010 
praejusios liūtys bei antroje vasaros pusejje paplitusi dryžligè, kurios fungicidais visiškai sustabdyti nepavyko. Magnio trąšų ịtaka vasarinių miežių derliui atskiruose bandymuose gauta skirtinga ( 3 lentelè).

Tręšiant $\mathrm{Mg}_{20}$ trąšų norma 5 bandymuose buvo stebimas vasarinių miežiu grūdų derliaus didèjimas, tačiau tik viename bandyme (Nr. 7) statistiškai patikimai $\mathrm{R}_{05}$ lygiui. Grūdų derlius mažèjo 4 bandymuose, iš jų 2 (Nr. 6 ir 8) statistiškai patikimai. Tręšiant $\mathrm{Mg}_{40}$ trąšų norma taip pat 5 bandymuose buvo stebimas grūdų derliaus didejimas, iš jų $3(\mathrm{Nr} .3,5,7)$ statistiškai patikimai $\mathrm{R}_{05}$ lygiui. Grūdų derlius 2 bandymuose patikimai mažèjo (Nr. 6, 8), o dar 2 - nepakito.

Vertinant $2008 \mathrm{~m}$. trijų bandymų vidurki $\mathrm{Mg}_{20}$ trąšų norma grūdų derlių padidino 2,1 \%, $\mathrm{Mg}_{40}-2,7 \%$. $2009 \mathrm{~m}$. šie rodikliai gauti atitinkamai $-0,97 \%$ ir $0,49 \%$, o 2010 m. - -2,3 \% ir $0 \%$. Taigi, tik $2008 \mathrm{~m}$. gauta miežių grūdų derliaus didejimo tendencija, o kitais bandymų metais - magnio trąšos derliaus neveikè arba nustatytos jo mažèjimo tendencijos.

Vertinant magnio trąšų ịtaką vasarinių miežių grūdų derliui (pagal mūsų suskirstytą dirvožemio karbonatingumą) nustateme, kad derliaus priedas, patręšus $\mathrm{Mg}_{20}$ trąšų norma, mažo karbonatingumo dirvožemiuose (judriojo magnio (A-L) yra $<200 \mathrm{mg} \mathrm{kg}^{-1}$, judriojo kalcio (A-L) - apie $1000 \mathrm{mg} \mathrm{kg}^{-1}, \mathrm{pH}_{\mathrm{KCl}}<5,0$, karbonatu $<0,1 \%$, bandymai Nr. $1,4,7)$ gautas esminis ir yra $4,4 \%$, vidutinio karbonatingumo (judriojo magnio (A-L) yra $250-300 \mathrm{mg} \mathrm{kg}^{-1}$, judriojo kalcio (A-L) apie
$2000 \mathrm{mg} \mathrm{kg}^{-1}, \mathrm{pH}_{\mathrm{KCl}} 5,1-6,0$, karbonatų 0,1-0,3\%, bandymai Nr. 2, 5, 8) - -2,7 \%, karbonatinguose (judriojo magnio (A-L) $>500 \mathrm{mg} \mathrm{kg}^{-1}$, judriojo kalcio (A-L) apie $4000 \mathrm{mg} \mathrm{kg}^{-1}, \mathrm{pH}_{\mathrm{KCl}}>6,5$, karbonatu $>0,3 \%$, bandymai Nr. $3,6,9)--2,5 \%$, t. y. vidutinio karbonatingumo ir karbonatinguose dirvožemiuose gautos grūdų derliaus mažèjimo tendencijos. Tręšiant $\mathrm{Mg}_{40}$ norma derliaus priedai gauti atitinkamai $3,8 \%,-1,6 \%, 0,64 \%$. Tai rodo, kad mūsų lauktas rezultatas, jog mažo karbonatingumo dirvožemiuose magnio trąšos labiausiai didins vasarinių miežiu grūdų derlių, kaip nurodo kai kurie autoriai (Lietuvos dirvožemių..., 1998; Bogdevitch, Mishuk, 2006), pasiteisino: patikimas $\mathrm{R}_{05}$ lygiui $2008-2010 \mathrm{~m}$. grūdų derliaus $4,4 \%$ priedas gautas patręšus $\mathrm{Mg}_{20}$ norma.

Vasarinių miežių šiaudų derlius vegetaciniame inde svyravo 8,6-15,7 g intervalo ribose. Vertinant $2008 \mathrm{~m}$. trijų bandymų vidurkị, patręšus $\mathrm{Mg}_{20}$ norma, šiaudų derliaus priedas gautas 5,0 \%, o tręšiant $\mathrm{Mg}_{40}$ trąšų norma - 6,0 \%. $2010 \mathrm{~m}$. šiaudų derliaus priedai sudare atitinkamai $10,0 \%$ ir $10,0 \%$ ir buvo patikimi $\mathrm{R}_{05}$ lygiui. $2009 \mathrm{~m}$. šiaudų derliaus priedų negauta, šie rodikliai buvo atitinkamai $0 \%$ ir $-1,3 \%$. Vertinant 2008-2010 m. išaugintą šiaudų derlių (pagal dirvožemio karbonatingumą) matome, kad visose išskirtose karbonatingumo grupèse gautas derliaus priedas, tačiau tik karbonatinguose dirvožemiuose jis buvo statistiškai patikimas $\mathrm{R}_{05}$ lygiui ir sudare atitinkamai 8,0 ir 8,8\%.

Apibendrinus visų 9 bandymų duomenis, vertinant atskirų metų ir bendrą trejų metų vidurkius nustatyta, jog tiek magnio $\mathrm{Mg}_{20}$, tiek ir $\mathrm{Mg}_{40}$ trąšų

3 lentelè. Magnio trąšų normų ịtaka vasarinių miežių derliui g/indui

Table 3. Spring barley yield (g per pot) as affected by magnesium fertilisation

\begin{tabular}{|c|c|c|c|c|c|c|c|c|c|c|c|c|c|c|c|c|}
\hline \multirow{3}{*}{$\begin{array}{c}\text { Trąšų } \\
\text { norma } \\
\text { Rate }\end{array}$} & \multicolumn{4}{|c|}{$2008 \mathrm{~m}$. } & \multicolumn{4}{|c|}{$2009 \mathrm{~m}}$. & \multicolumn{4}{|c|}{$2010 \mathrm{~m}}$. & \multicolumn{4}{|c|}{$2008-2010 \mathrm{~m}$. } \\
\hline & \multicolumn{16}{|c|}{ Bandymo Nr. / Experiment No. } \\
\hline & 1 & 2 & 3 & $\overline{\mathbf{x}}$ & 4 & 5 & 6 & $\overline{\mathbf{x}}$ & 7 & 8 & 9 & $\overline{\mathbf{x}}$ & $1,4,7$ & $2,5,8$ & $3,6,9$ & $\overline{\mathbf{x}}$ \\
\hline \multicolumn{17}{|c|}{ Grūdai (15\% drègnumo) / Grain (15\% moisture) } \\
\hline $\mathrm{Mg}_{0}$ & 20,0 & 19,7 & 16,2 & 18,6 & 21,1 & 20,0 & 20,6 & 20,6 & 13,8 & 14,6 & 9,9 & 12,8 & 18,3 & 18,1 & 15,6 & 17,3 \\
\hline $\mathrm{Mg}_{20}$ & 20,8 & 19,4 & 16,7 & 19,0 & 21,3 & 20,5 & 19,4 & 20,4 & 15,3 & 12,8 & 9,4 & 12,5 & 19,1 & 17,6 & 15,2 & 17,3 \\
\hline $\mathrm{Mg}_{40}$ & 20,0 & 20,3 & 17,1 & 19,1 & 21,1 & 21,2 & 19,7 & 20,7 & 15 , & 12,0 & 10 & 12,8 & 19,0 & 17,8 & 15,7 & 17,5 \\
\hline $\mathrm{R}_{05}$ & 1,21 & 0,72 & 0,68 & 0,51 & 1,17 & 0,98 & 0,67 & 0,61 & 1,27 & 1,64 & 1,09 & 1,08 & 0,70 & 0,91 & 0,55 & 0,42 \\
\hline \multicolumn{17}{|c|}{ Šiaudai (s. m.) / Straw (dry matter) } \\
\hline $\mathrm{Mg}_{0}$ & 11,2 & 10,2 & 8,6 & 10,0 & 15,3 & 14,8 & 15,6 & 15,2 & 11,8 & 11,5 & 9,8 & 11,0 & 12,7 & 12,2 & 11,3 & 12,1 \\
\hline $\mathrm{Mg}_{20}$ & 12,2 & 10,2 & 9,0 & 10,5 & 15,2 & 14,9 & 15,6 & 15,2 & 11,8 & 12,5 & 12,0 & 12,1 & 13,1 & 12,5 & 12,2 & 12,6 \\
\hline $\mathrm{Mg}_{40}$ & 11,8 & 10,5 & 9,4 & 10,6 & 14,3 & 14,9 & 15,7 & 15,0 & 13,1 & 11,5 & 11,8 & 12,1 & 13,1 & 12,3 & 12,3 & 12,6 \\
\hline $\mathrm{R}_{05}$ & 0,83 & 0,73 & 0,83 & 0,42 & 0,95 & 1,25 & 1,35 & 0,59 & 0,55 & 0,47 & 0,80 & 0,60 & 0,63 & 0,47 & 0,63 & 0,33 \\
\hline
\end{tabular}


normos vidutiniškai miežių šiaudų derlių didino 4,1 \%. Mažai karbonatinguose dirvožemiuose grūdų derlių esminiu 4,4 \% skirtumu didino tręšimas $\mathrm{Mg}_{20}$ norma.

Svarbus grūdų kokybès rodiklis - grūdų stambumas, todèl bandymuose nustatème 1000 grūdų masę (4 lentelè). Tyrimai parodè, kad, vasarinius miežius patręšus $\mathrm{Mg}_{20}$ trąšų norma, gautas 1000 grūdų masès didejimas 8 bandymuose, tačiau tik viename iš jų statistiškai patikimam $\mathrm{R}_{05}$ lygiui. $\mathrm{Pa}$ našiai gauta ir tręšiant $\mathrm{Mg}_{40}$ norma - grūdų masè didejo 7 bandymuose, tačiau taip pat tik viename statiškai patikimai. 2008-2010 m. visų bandymų vidurkis parode, jog tręšimas $\mathrm{Mg}_{20}$ norma 1000 grūdų masę padidino 2,6 \%, o miežius patręšus didesne $\mathrm{Mg}_{40}$ norma, grūdų mase padidèjo mažiau $-2,4 \%$, ir gauti priedai abiem atvejais buvo statistiškai patikimi $\mathrm{R}_{05}$ lygiui.

Magnio kiekis vasarinių miežių grūduose tyrimų metais svyravo $0,10-0,13 \%$ intervalo ribose, o šiauduose 0,07-0,14\% ribose (5 lentelè). Magnio trą̧̌os neturèjo ịtakos magnio kiekiui grūduose, tačiau jo daugiau nustatyta karbonatinguose dirvožemiuose, nes, 2008-2010 m. vidutiniais duomenimis, jo grūduose mažai karbonatinguose dirvožemiuose buvo $0,11 \%$, vidutiniškai karbonatinguose $-0,12 \%$, karbonatinguose $-0,13 \%$.

Tręšimas $\mathrm{Mg}_{20}$ ir $\mathrm{Mg}_{40}$ normomis magnio kiekị šiauduose karštais 2010 m. didino. Patręšus šiomis magnio normomis, jo kiekis, palyginti su kontrole, padidèjo nuo 0,08 iki $0,10 \%$. Tačiau 2008 ir 2009 m. tręštuose magniu šiauduose jo kiekio didejimas nebuvo statistiškai patikimas.

Žaliųjų proteinų kiekis vasarinių miežiu grūduose svyravo 10,2-14,7\% ribose, o šiauduose 2,3-4,6 \% ribose (6 lentelè). Magnio trąšos didino žaliụjų proteinų kiekị vasarinių miežių grūduose ir vertinant visus metus kartu jų vidurkis netrę- šiant magniu buvo $11,03 \%$, tręšiant $\mathrm{Mg}_{20}$ norma $-11,86 \%$ ir tręšiant $\mathrm{Mg}_{40}$ norma - 12,5\%. Net 7 bandymuose, patręšus vasarinius miežius $\mathrm{Mg}_{20}$ trąšų norma, buvo gautas žaliųjų proteinų kiekio padidejimas ir jis sudarè 5,9\%, palyginti su netręštais. Padidinus magnio trąšų normą iki $\mathrm{Mg}_{40}$, šiuose bandymuose žaliųjų proteinų kiekis padidèjo net 15,8 \%, palyginti su netręštais magniu.

Vertinant kiekvienų metų trijų bandymų žaliųjų proteinų kiekị grūduose nustatyta, kad tręšiant $\mathrm{Mg}_{20}$ norma $2008 \mathrm{~m}$. žaliųjų proteinų kiekis padidèjo 8,5\%, 2009 m. - 2,8 \%, o 2010 m. - $11 \%$. Patręšus miežius $\mathrm{Mg}_{40}$ trąšų norma, žaliųjų proteinų kiekis, palyginti su kontrole, padidejo atitinkamai $19,8 \%, 9,3 \%$ ir $11 \%$.

Magnio trąšos didino ir žaliųjų proteinų kieki šiauduose. Trijų metų vidutiniais duomenimis, tręšiant $\mathrm{Mg}_{20}$ trąšų norma žaliųjų proteinų kiekis padidèjo atitinkamai: $2008 \mathrm{~m}$. - $23 \%$, 2009 m. - 3,8 \%, 2010 m. - 5,7 \%, o tręšiant $\mathrm{Mg}_{40}$ norma $-13,3,7,7$ ir $22,8 \%$.

Koreliacinè analizè tarp dirvožemio agrocheminių rodiklių ir vasarinių miežių grūdų derliaus parodè, kad didelès įtakos derliui turejjo judriojo magnio kiekis, nustatytas Egner-Riehm-Domingo metodu, ir vandenyje tirpus magnis, o taip pat judriojo kalcio kiekis ir dirvožemio pH (7 lentelè). Magnio kieki grūduose didino judriojo magnio kiekis, nustatytas visais metodais, išskyrus vandeninejje ištraukoje. Didelès ịtakos magnio kiekiui grūdų derliuje turèjo dirvožemio $\mathrm{pH}$, kiek mažiau veike judrusis kalcio, karbonatų bei humuso kiekis dirvožemyje. Koreliacinè analizè parodè, kad žaliujų proteinų kiekio grūduose atskiri dirvožemio agrocheminių savybių rodikliai patikimai nedidino. Stiprus koreliacinis ryšys nustatytas tarp derliaus priedo, patręšus $\mathrm{Mg}_{20}$ magnio trąšų norma, ir judriojo magnio bei judriojo kalcio kiekio

4 lentelè. Magnio trąšų normų ịtaka vasarinių miežių 1000 grūdų masei (g)

Table 4. Mass of 1000 spring barley grains ( $\mathrm{g}$ ) as affected by magnesium fertilisation

\begin{tabular}{|c|c|c|c|c|c|c|c|c|c|c|c|c|}
\hline \multirow{3}{*}{$\begin{array}{c}\text { Trąšù } \\
\text { norma } \\
\text { Rate }\end{array}$} & \multicolumn{4}{|c|}{$2008 \mathrm{~m}}$. & \multicolumn{4}{|c|}{$2009 \mathrm{~m}$. } & \multicolumn{4}{|c|}{$2010 \mathrm{~m}}$. \\
\hline & \multicolumn{12}{|c|}{ Bandymo Nr. / Experiment No. } \\
\hline & 1 & 2 & 3 & $\overline{\mathbf{x}}$ & 4 & 5 & 6 & $\overline{\mathbf{x}}$ & 7 & 8 & 9 & $\overline{\mathbf{x}}$ \\
\hline $\mathrm{Mg}_{0}$ & 45,91 & 48,87 & 48,60 & 47,79 & 46,79 & 51,81 & 49,45 & 49,35 & 39,83 & 40,39 & 42,25 & 40,82 \\
\hline $\mathrm{Mg}_{20}$ & 47,60 & 49,32 & 50,25 & 49,06 & 48,66 & 50,82 & 49,66 & 49,71 & 41,16 & 42,24 & 45,15 & 42,85 \\
\hline $\mathrm{Mg}_{40}$ & 46,80 & 48,69 & 51,27 & 48,92 & 48,01 & 50,98 & 50,34 & 49,78 & 40,28 & 40,88 & 46,39 & 42,52 \\
\hline $\mathrm{R}_{05}$ & 1,59 & 0,46 & 2,77 & 0,99 & 2,72 & 2,31 & 1,59 & 1,05 & 1,19 & 2,45 & 3,64 & 1,39 \\
\hline
\end{tabular}



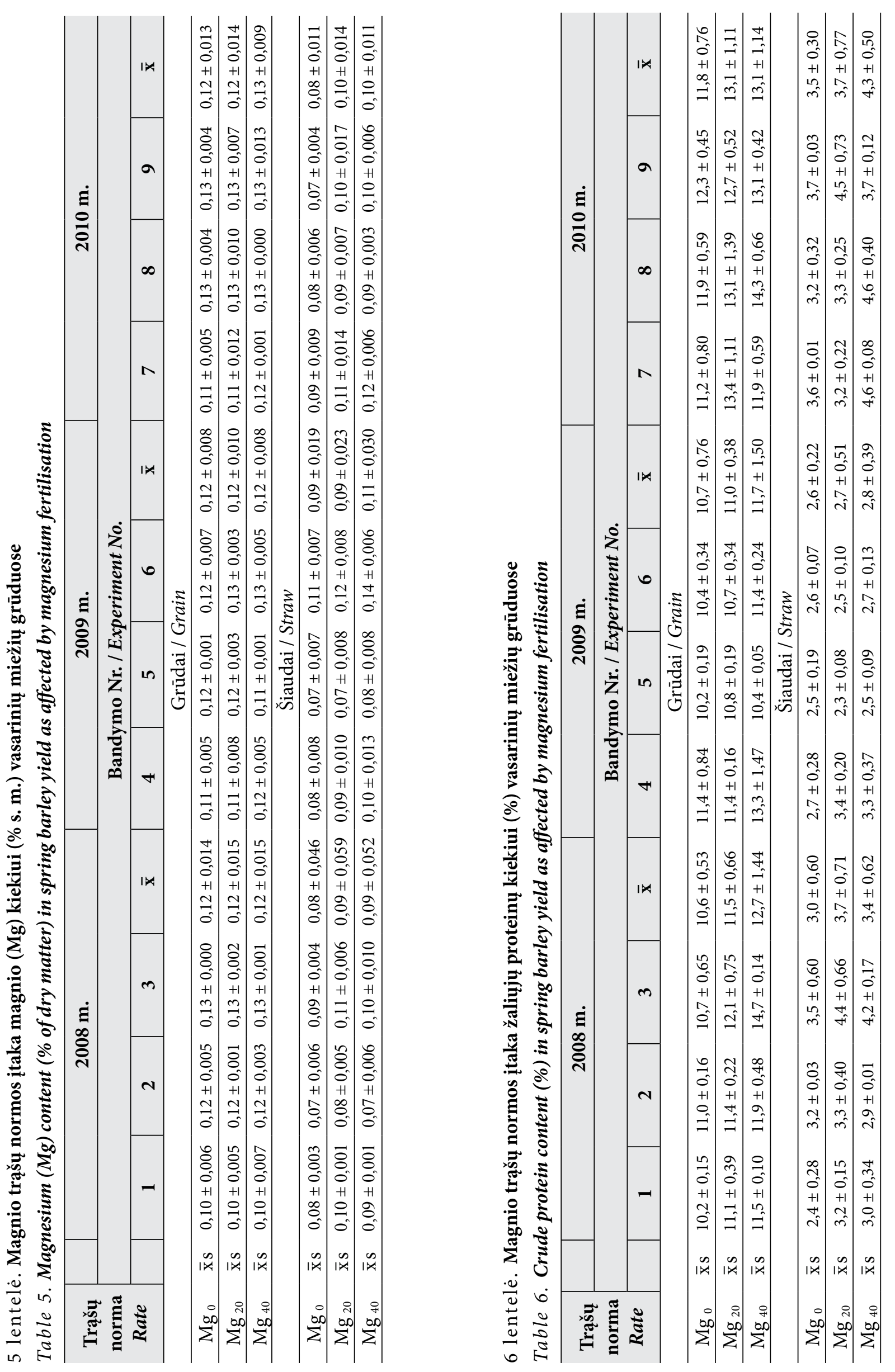
7 lentelè. Koreliacinè priklausomybẻ tarp dirvožemio agrocheminių rodiklių ir vasarinių miežių grūdų derliaus, jame esančio magnio, žaliųjų proteinų kiekio ir derliaus priedo

Table 7. Correlative dependence between the spring barley grain yield, yield increase, magnesium and crude protein content in grain and the agrochemical properties of soil

\begin{tabular}{|c|c|c|c|c|c|}
\hline \multirow{3}{*}{$\begin{array}{l}\text { Dirvožemio agrocheminiai rodikliai }(\mathrm{x}) \\
\text { Agrochemical properties of soil }\end{array}$} & \multicolumn{5}{|c|}{$\mathbf{Y}$} \\
\hline & \multirow{2}{*}{$\begin{array}{l}\text { Derlius Mg } \\
\quad \text { Yield }\end{array}$} & \multirow{2}{*}{$\begin{array}{c}\text { Magnio } \\
\text { kiekis } \\
\text { Magnesium } \\
\text { content } \\
\end{array}$} & \multirow{2}{*}{$\begin{array}{c}\text { Žaliųjų protei- } \\
\text { nų kiekis } \\
\text { Crude protein } \\
\text { content }\end{array}$} & \multicolumn{2}{|c|}{$\begin{array}{l}\text { Derliaus priedas } \\
\text { Yield increase }\end{array}$} \\
\hline & & & & $\mathrm{Mg}_{20}$ & $\mathrm{Mg}_{40}$ \\
\hline \multicolumn{6}{|c|}{$\begin{array}{l}\text { Judriojo } \mathrm{Mg} \text { kiekis }\left(\mathrm{mg} \mathrm{kg}^{-1}\right) \\
\text { Plant available } \mathrm{Mg} \text { content }\left(\mathrm{mg} \mathrm{kg}^{-1}\right) \text { : }\end{array}$} \\
\hline A-L & $0,616^{* *}$ & $0,492^{\star}$ & 0,380 & $0,491^{\star *}$ & 0,088 \\
\hline $\mathrm{Me}-3$ & 0,289 & $0,582^{*}$ & 0,026 & 0,214 & 0,002 \\
\hline $\mathrm{KCl}$ & 0,046 & $0,540^{*}$ & 0,228 & 0,030 & 0,074 \\
\hline $\mathrm{NH}_{4} \mathrm{OAC}$ & 0,03 & $0,539^{*}$ & 0,239 & 0,007 & 0,074 \\
\hline $\mathrm{CaCl}_{2}$ & 0,118 & $0,535^{\star}$ & 0,196 & 0,046 & 0,070 \\
\hline $\mathrm{H}_{2} \mathrm{O}$ & $0,735^{\star *}$ & 0,2 & 0,359 & 0,099 & 0,163 \\
\hline $\begin{array}{c}\text { Judriojo Ca kiekis }\left(\mathrm{mg} \mathrm{kg}^{-1}\right) \\
\text { Plant available Ca content }\left(\mathrm{mg} \mathrm{kg}^{-1}\right)\end{array}$ & $0,639^{\star *}$ & $0,525^{\star}$ & 0,403 & $0,511^{\star *}$ & 0,100 \\
\hline $\mathrm{pH}_{\mathrm{KCl}}$ & $0,432^{\star *}$ & $0,808^{\star *}$ & 0,188 & $0,378^{*}$ & 0,100 \\
\hline $\begin{array}{l}\text { Karbonatu kiekis (\%) } \\
\text { Carbonate content (\%) }\end{array}$ & 0,041 & $0,550^{*}$ & 0,048 & 0,243 & 0,080 \\
\hline $\begin{array}{l}\text { Humuso kiekis (\%) } \\
\text { Humus content (\%) }\end{array}$ & 0,037 & $0,499^{*}$ & 0,131 & 0,021 & 0,025 \\
\hline
\end{tabular}

${ }^{* *} \mathrm{P}<0,01,{ }^{*} \mathrm{P}<0,05$.

dirvožemyje, įvertintų Egner-Riehm-Domingo metodu, silpnesnis ryšys su dirvožemio $\mathrm{pH}$. Tarp derliaus priedo, gauto vasarinius miežius patręšus $\mathrm{Mg}_{40}$ trąšų norma, ir dirvožemio agrocheminių rodiklių koreliacinio ryšio negauta.

Vasariniai miežiai, kurie nebuvo tręšti magnio trąšomis, per vegetaciją atskiruose bandymuose sunaudojo 18-38 $\mathrm{mg}$ magnio $(\mathrm{Mg})$ vienam vegetaciniam indui arba vidutiniškai $27 \mathrm{mg}$ (8 lentelè). Skaičiuojant vienam kvadratiniam metrui vidutiniškai sudare $0,71 \mathrm{~g}$. Tręšti magnio trąšomis augalai magnio sunaudojo šiek tiek daugiau: $\mathrm{Mg}_{20}$ norma - atitinkamai $22-41 \mathrm{mg}$, arba vidutiniškai $30 \mathrm{mg}$; $\mathrm{Mg}_{40}$ norma - 24-44 ir $31 \mathrm{mg}$. Ši magnio kiekị augalai įsavino iš dirvožemio.
Augalus patręšus $\mathrm{Mg}_{20}$ norma, $\mathfrak{i}$ vegetacinị indą pateko $75 \mathrm{mg}$ magnio $(\mathrm{Mg})$, o augalai per vegetaciją vidutiniškai sunaudojo tik $44 \%$ to kiekio. Patręšus $\mathrm{Mg}_{40}$ norma, augalai sunaudojo vos $23 \%$ to kiekio. Tai rodo, kad vasariniai miežiai jau ir tręšti $\mathrm{Mg}_{20}$ norma nepanaudojo daugiau negu pusès magnio trąšú, o didinti magnio trąšų normą iki $\mathrm{Mg}_{40}$ yra visai netikslinga.

Apibendrinant galima teigti, kad tręšimas magnio trąšomis yra efektyvus tik rūgščiuose, nedaug judriojo kalcio ir magnio turinčiuose dirvožemiuose. Verta būtų išsamiau panagrinèti mažesnę trąšų normą nei $\mathrm{Mg}_{20}$, nes bandymų magnio balansas rodo, kad tręšiant šia norma augalai nepanaudojo daugiau nei pusès magnio trąšų. Taip pat

\section{8 lentelè. Magnio (Mg) balansas (mg/indui)}

Table 8. Magnesium (Mg) balances (mg per pot) in experiments

\begin{tabular}{|c|c|c|c|c|c|c|c|c|c|c|}
\hline \multirow{2}{*}{$\begin{array}{c}\text { Trąšų } \\
\text { norma } \\
\text { Rate }\end{array}$} & \multicolumn{9}{|c|}{ Bandymo Nr. / Experiment No. } & \multirow{2}{*}{$\overline{\mathbf{x}}$} \\
\hline & 1 & 2 & 3 & 4 & 5 & 6 & 7 & 8 & 9 & \\
\hline $\mathrm{Mg}_{0}$ & $-26 \pm 0,4$ & $-28 \pm 0,8$ & $-26 \pm 1,2$ & $-32 \pm 0,3$ & $-31 \pm 0,9$ & $-38 \pm 0,8$ & $-23 \pm 0,6$ & $-26 \pm 0,2$ & $-18 \pm 1,2$ & $-27 \pm 1,0$ \\
\hline $\mathrm{Mg}_{20}$ & $46 \pm 0,3$ & $47 \pm 0,05$ & $46 \pm 0,3$ & $40 \pm 2,4$ & $44 \pm 0,9$ & $34 \pm 1,4$ & $47 \pm 1,6$ & $49 \pm 1,3$ & $53 \pm 0,8$ & $45 \pm 1,0$ \\
\hline $\mathrm{Mg}_{40}$ & $123 \pm 0,4$ & $122 \pm 0,2$ & $122 \pm 0,6$ & $117 \pm 0,8$ & $117 \pm 1,0$ & $106 \pm 2,0$ & $117 \pm 2,1$ & $126 \pm 0,7$ & $126 \pm 2,0$ & $119 \pm 1,0$ \\
\hline
\end{tabular}


magnio trąšų normos parinkimas pagal judriojo magnio kieki dirvožemyje ji nustatant 6 Europos šalyse naudojamais metodais nepasiteisino. Didesnè koreliacinè priklausomybè gauta magni nustatant Lietuvoje naudojamu Egner-Riehm-Domingo metodu ir vandens ištraukoje. Tai parodo, kad judriojo magnio kiekio nustatymui verta naudoti stipresnius tirpiklius. Vandenyje tirpus magnis augalams taip pat yra labai svarbus, nes rodo augalams prieinamą įsisavinti magnio kiekị.

\section{IŠVADOS}

1. Atlikti devyni vegetaciniai bandymai iš ịvairių Lietuvos vietų surinktuose skirtingo karbonatingumo dirvožemiuose parodè, kad magnio trąšų $\mathrm{Mg}_{20}$ norma didino vasarinių miežių grūdų derlių tik mažo karbonatingumo dirvožemiuose. Tokiuose dirvožemiuose judriojo magnio $\left(\mathrm{Mg}_{\mathrm{A}-\mathrm{L}}\right)$ kiekis sudare $135-273 \mathrm{mg} \mathrm{kg}{ }^{-1}$, kalcio $\left(\mathrm{Ca}_{\mathrm{A}-\mathrm{L}}\right)$ - 912-1 $894 \mathrm{mg} \mathrm{kg}^{-1}$, karbonatai - 0-0,08\%, $\mathrm{pH}_{\mathrm{KCl}}-4,3-5,3$, o vasarinių miežių grūdų derliaus priedas tręšiant $\mathrm{Mg}_{20}$ norma buvo 4,4 \%. Vidutinio karbonatingumo ir karbonatinguose dirvožemiuose grūdų derliaus $\mathrm{Mg}_{20}$ ir $\mathrm{Mg}_{40}$ normos nedidino.

2. Šiaudų derlių magnio trąšų $\mathrm{Mg}_{20}$ ir $\mathrm{Mg}_{40}$ normos skirtingo karbonatingumo dirvožemiuose vidutiniškai didino $4,1 \%$, tačiau iš esmès - tik 4 bandymuose (bandymai Nr. 1, 7, 8, 9) ir tik viename (bandymo Nr. 4) $\mathrm{Mg}_{40}$ norma ji iš esmès mažino. Karbonatinguose dirvožemiuose šiaudų derliaus priedai gauti didesni.

3. Tręšimas magniu didino vasarinių miežių grūdų stambumą: $\mathrm{Mg}_{20}$ norma 1000 grūdų masę vidutiniškai padidino $2,6 \%, \mathrm{Mg}_{40}-2,4 \%$. Mažo karbonatingumo dirvožemiuose, patręšus $\mathrm{Mg}_{20}$ norma, padidejimas buvo esminis, vidutinio karbonatingumo ir karbonatinguose dirvožemiuose nustatytos tik didejimo tendencijos.

4. Magnio trąšos, nepriklausomai nuo dirvožemio karbonatingumo, daugelyje bandymų iš esmès didino žaliųjų proteinų kiekị grūduose ir šiauduose. $\mathrm{Mg}_{20}$ norma grūduose žaliuosius proteinus vidutiniškai padidino $8,2 \%$, $\mathrm{Mg}_{40}-13,6 \%$, šiauduose atitinkamai 9,9 \% ir $15,1 \%$.

5. Magnio trąšos neturejjo įtakos magnio kiekiui grūduose, tačiau jo daugiau nustatyta karbonatinguose dirvožemiuose išaugintuose grūduo- se. Magnio kiekis nuo magnio trąšų šiauduose nesikeitè, tačiau karštais metais jo kiekis didèjo. Magnio augalai bandymuose vidutiniškai sunaudojo $0,71 \mathrm{~g} / \mathrm{m}^{2}$ arba $44 \% \mathrm{Mg}_{20}$ normos kiekio.

6. Gauta iš esmès patikima koreliacinè priklausomybè tarp miežių grūdų derliaus ir judriojo magnio kiekio dirvožemyje, nustatyto EgnerRiehm-Domingo metodu $(r=0,616, P<0,01)$, ir vandens ištraukoje $(r=0,735, P<0,01)$. Kai judrusis magnis dirvožemyje buvo nustatytas kalcio chlorido, kalio chlorido, amonio acetato ir Mehlich 3 metodais, koreliacinès priklausomybès negauta.

Gauta 20121031

Priimta 20130122

\section{LITERATŪRA}

1. Bergmann W. 1986. Ernährungsstörungen bei Kulturpflanzen. Entstehung, visuelle und analytische Diagnose. Jena: VEB Gustav Verlag. P. 166178.

2. Budnakova M., Čermak P. 2009. Fertilising recommendation system based on results of agrochemical soil testing. Fertilizer and Fertilization. No. 37. P. 149-159.

3. Carmak I., Kirkby E. 2007. Role of Magnesium Nutrition in Growth and Stress Tolerance. York, UK: The International Fertilizer Society. $24 \mathrm{p}$.

4. Fotyma M., Dobers E. S. 2008. Soil testing methods and fertilizer recommendations in Central-Eastern European countries. Fertilizer and Fertilization. No. 30. P. 6-93.

5. Jadczyszyn T. 2009. The Polish fertilization recommendation system Naw Sald. Fertilizer and Fertilization. No. 37. P. 195-203.

6. Johnson A. E. 2007. Potassium, Magnesium and Soil Fertility: Long Term Experimental Evidence. York, UK: The International Fertilizer Society. $40 \mathrm{p}$.

7. Mažvila J., Vaičys M., Buivydaite V. V. 2006. Lietuvos dirvožemiu makromorfologine diagnosti$k a$. Lietuvos žemdirbystès institutas. P. 203-222.

8. Riktlinjer för gödsling och kalkning 2009. Jordbruksinformation. 2008. No. 26 [žiūrèta 201210-04]. Prieiga per interneta: http://www2.jordbruksverket.se/webdav/files/SJV/trycksaker/Pdf_ jo/jo08_26.pdf

9. Ristimäki L. 2007. Potassium and Magnesium Fertiliser Recommendations in Some European Countries. York, UK: The International Fertilizer Society. $31 \mathrm{p}$. 
10. Roemheld V., Kirkby E. A. 2007. Magnesium Functions in Crop Nutrition and Yield. York, UK: The International Fertilizer Society. 24 p.

11. Schweder P., Kape H. E. Düngung. 2004. Hinweise und Richtwerte für die landwirtschaftliche Praxis, Leitfaden yur Umsetzung der Düngeverordnung. Rostock. P. 69-75.

12. Staugaitis G., Rutkauskiene R. 2010. Comparison of magnesium determination methods as influenced by soil properties. Žemdirbysté-Agriculture. Vol. 97. No. 3. P. 105-116.

13. Tripolskaja L. ir kt. 2010. Rūgščių dirvožemių cheminių savybių optimizavimas. Agroekosistemu komponentu valdymas: ilgalaikiu agrocheminiu tyrimu rezultatai. Akademija, Kèdainių r. P. 99-113.

\section{Gediminas Staugaitis, Rasa Rutkauskienè}

\section{EFFECT OF MAGNESIUM FERTILISER ON SPRING BARLEY PLANTS GROWN IN DIFFERENT TYPES OF SOIL}

\section{Sum mary}

Pot experiments were conducted at the Agrochemical Research Laboratory of the Lithuanian Research Centre for Agriculture and Forestry in 2008-2010. A total of 9 experiments were performed. 'Simba' variety spring barley plants were sown into pots filled with soil containing different amounts of carbonates. Two rates of the magnesium fertiliser were applied - $2 \mathrm{~g}\left(\mathrm{Mg}_{20}\right)$ and $4 \mathrm{~g}\left(\mathrm{Mg}_{40}\right)$ of magnesium $(\mathrm{Mg})$ per $\mathrm{m}^{2}$. Our research evidence suggests that the $\mathrm{Mg}_{20}$ rate increased the spring barley grain yield only in carbonatepoor soils. The plant available magnesium content $\left(\mathrm{Mg}_{\mathrm{A}-\mathrm{L}}\right)$ in these soils was $135-273 \mathrm{mg} \mathrm{kg}^{-1}$, calcium $\left(\mathrm{Ca}_{\mathrm{A}-\mathrm{L}}\right)$ was $912-$ $1894 \mathrm{mg} \mathrm{kg}^{-1}$, carbonates were $0-0.08 \%, \mathrm{pH}_{\mathrm{KCl}}$ was $4.3-5.3$; the $\mathrm{Mg}_{20}$ fertilisation rate increased the grain yield by $4.4 \%$. $\mathrm{Mg}_{20}$ and $\mathrm{Mg}_{40}$ fertilisation rates increased the straw production by $4.1 \%$ on an average, yet this increase was statistically significant only in 4 experiments. Magnesium fertilisation statistically significantly increased the crude protein content in grains and straw in most cases and irrespective of the carbonate content in soil. The $\mathrm{Mg}_{20}$ fertilisation rate increased the crude protein content in grains by $8.2 \%$ on an average, $\mathrm{Mg}_{40}$ by $13.6 \%$, and in straw by $9.9 \%$ and $15.1 \%$, respectively. Magnesium fertilisation had no significant effect on the magnesium content in grains, yet higher levels of the magnesium content were determined in grains of plants grown in carbonate-rich soils. The content of magnesium in straw did not depend on magnesium fertilisation; higher levels of the magnesium content in straw were determined when the growing season was warmer than usual. Spring barley plants consumed $0.71 \mathrm{~g} \mathrm{~m}^{2}$ or $44 \%$ of $\mathrm{Mg}_{20}$ rate on an average for all 9 experiments. The spring barley grain yield increase correlated with the plant available magnesium content in soil determined using the A-L method $(r=0.616, P<0.01)$ and the water extraction method $(r=0.735, P<0.01)$. Any correlative interdependence was not found when the plant available magnesium content in soil was determined using other methods: calcium chloride, potassium chloride, ammonium acetate and Mehlich 3.

Key words: spring barley, magnesium fertiliser, magnesium in soil 